\title{
Profitability analysis of poultry egg production and marketing in Southern zone of Plateau State, Nigeria
}

Latu, M. Y., Wumnokol, D. P. and Guluwa, L. Y.

Plateau State College of Agriculture, P.M.B 001 Garkawa

Abstract

Corresponding author email- latuymoses@gmail.com

Data from a survey in Southern zone of Plateau State was used to assess profitability of egg production and marketing in five markets of Southern Plateau. Primary data was obtained by means of personal interview through the use of a well-structured questionnaire administered to 20 individuals in each of the five markets (Langtang market, Shendam (Nshar) market, Namu market, Garkawa market and Mabudi market). The socio-economic characteristic of the respondents shows that most of them were experienced in the business and were mostly females (96\%). The estimated Gini coefficient was 0.81296 which implies that there is a high level of inequality in the production and sole revenue of the respondents. While the gross margin reveals that marketing of eggs in the study area is profitable with gross margin per seller as N12, 029.50 and the benefit cost ratio also reveals that egg marketing is viable in the study area as N10, 799.50 per seller. It is therefore recommended as a means of gainful employment and mitigation to urban migration.

\section{Keywords-Profitability, egg production, marketing}

\section{Introduction}

Table eggs refer to infertile eggs produced by commercial poultry layers and used mainly for consumption by man. "Hatchable Egg", on the other hand, are fertile eggs produced by allowing selected male and female breeder stock either pullet or broiler chicken to run, perch and mate freely. While both types of eggs are consumable, table eggs have longer shelf life than fertile eggs. The fertile eggs when freshly laid has excellent interior quality, but the rate of it germ cell (ovule) development when the egg is held at ambient tropical temperature soon renders the egg unfit as food. It is only by holding fertile eggs at temperatures of $15-20^{\circ} \mathrm{C}$ that can arrest germ cell development. Hence, in egg trade, it is infertile (table) eggs they are ordinarily produced and offered for sale to consumers. Egg is a unique source of low calorie, well balanced and easily digested nutrients for humans of all ages, particularly children, elderly people and convalescent. It is recommended that, an adult human should consume one egg daily (Okuneye, 2002). Weight for weight, an egg contains about the same amount of protein as poultry meat and pork and about three quarters that of beef and two thirds that of whole milk cheese (FA O, 2003).

Egg marketing, according to Afolabi (2007) and Ekunwe and Abufohai (2009) is a profitable enterprise and gainful employment opportunity. Therefore, it is a genuine means of income generation and poverty alleviation as poultry is widely consumed in Nigeria, not only because it is a rich source of high quality protein, but because there is little or no religious and social taboo in all parts of the country against its consumptions. Experience has shown that poultry eggs and meat are always in short supply and at exorbitant prices in rural areas where the dwellers depend on egg supply of poultry farmers who invariably are in urban and peri urban countries (Fasakin, 1984).

Therefore, there is need to study whether the egg marketers in the Southern zone of Plateau State have the attributes to run an efficient egg marketing enterprise. The socio economic characteristics, relevant activities of the egg producers and 


\section{Profitability analysis of poultry egg production and marketing}

marketers along site with the profitability of egg production and marketing in the study area needs to be determined, as well as the constraints encountered by the respondents. This study was therefore conducted to assess the profitability and marketing analysis of egg Production in Southern Zone of Plateau State.

\section{Material and methods Studyarea}

The study area for this research comprises six local government areas namely: Langtang South, Langtang North, Wase, Mikang, Shandam and Quanpan local government. The zone is located in the southern guinea savanna zone of Nigeria with an area of 8.966 square kilometer which lies between latitude $80^{\circ} 24^{\circ} \mathrm{N}$ and Longitude $80^{\circ} 32^{\circ}$ and $10^{\circ} 38^{\circ}$ East (Ashigidigbi et al., 2011).

\section{Sampling techniques and size}

A two (2) stage sampling technique was used in selecting the respondents. The first stage was purposive sampling 5 (five) markets from the zone: Langtang, Shendam (Nshar), Namu, Garkawa and Mabudi markets. The second stage was the selection of 20 (twenty) egg producers and marketers from each of the markets mentioned above using random sampling techniques. This brings to a total of 100 (hundred) sample of respondents.

\section{Data collection}

Primary data was obtained by means of personal interview through the use of well structured questionnaires administered randomly to twenty respondents in each market as this gave them equal chance to be selected.

\section{Data analysis}

Descriptive statistics such as frequencies, percentages and mean were used to analyze some socio-economic characteristics of the respondents. Gross margin analysis was used to determine the profitability of egg production and marketing as $\mathrm{Gm}=\mathrm{Gs}$ TVC

Where: $\mathrm{Gm}=$ Gross Margin

$\mathrm{Gs}=$ Gross sales

TVC $=$ Total Variable Cost

The marketing margin for molar was used to analyze the marketing margin of egg in the study area. The marketing margin given as Retail price minus farm gate price was used to determine the egg marketing system while the viability of the business was assessed using the Benefit Cost Ratio (BCR)

$\mathrm{BCR}=\mathrm{PV}$ of total revenue divides by PV of total cost

Where: PV total revenue $=$ present value of Revenue

PV total cost $=$ Present value of cost.

Decision criteria state that the business is profitable or viable if the BCR is greater than or equal to 1 .

\section{Results and discussions \\ Socio economic characteristics}

The results presented in Table 1 showed that $96.7 \%$ (92) of the eggs producers and marketers were females. This may imply that, egg marketing and production is a feminine business. This result was in agreement with the study carried out by Afolabi (2007) on poultry egg in South Western Nigeria, which showed a dominating female population of egg producers and marketers in the study area $(80.5 \%)$. This result also showed that the average of the respondents were within the range of 31 - 40 years old with $53.2 \%$ follow by $41-50$ years with $20.6 \%$. This may mean that most eggs marketers in the Southern Zone of Plateau State were in their active age of productivity as this agreed with the findings of Afolabi (2007), that majority $(89 \%)$ of poultry egg producers and marketers in South Western Nigeria were between 30 and 50 years. 


\section{Latu, Wumnokol. and Guluwa}

The result presented in Table 1 also shows that $73(88.3 \%)$ of the respondents were married with an average house hold size of 2 - 4 persons $(40.2 \%)$, having an average of secondary education $46.61 \%$. This implied that most of the poultry egg producers and marketers in the Southern Zone of Plateau State did not have large household sizes and were not completely illiterates. The result also demonstrated that most of the poultry egg marketers in the zone were retailers 76 $(75.7 \%)$ with few whole sellers that are quite experience in the business.

Table 1: Summary statistics of Socio - economic characteristics of Respondents

Items

Gender

Males

Females

Total

Married Status

Married

Single

Widowed

Total

Age (in years)

Less than 20

8

2

$20-30$

$31-40$

$41-50$

51 and above

Total

Level of Education

Primary

Secondary

Tertiary

Total

House hold size

$1-2$

$2-4$

$5-6$

7 and above

Total

Type of seller

Producer

Retailer

Whole seller

Total

Source: Field Survey 2018

Respondents

92

100

73

25

100

15

Percentage

3.3

96.7

100

88.3

10.0

1.7

100

8.2

15.8

53.2

20.6

2.2

100

100

36.67

46.67

16.66

100

23.8

40.2

24.0

12.0

100

100

75.7

21.0

100 


\section{Profitability analysis of poultry egg production and marketing}

\section{Market structure of respondents}

The result as presented in Table 2 below shows that the estimated Gini Coefficient was 0.81296 . This implies that there is high level of inequality in the production and sales revenue of the respondents and consequently, high level of concentration. This is a reflection of the inefficiency in the market structure of the egg in the study area. Also, the result shows that $41(68.8 \%)$ of the respondents bought eggs from producers while $19(31.7 \%)$ of them both from wholesalers. This implies that most of the egg producers and marketers in Southern Zone of Plateau State normally prefer to buy from producers if there are any supplies, also, $43(71.7 \%)$ of respondents sold only to consumers. This indicates a high level of decentralization in the marketing channel for egg in the study area.

Table 2: Estimate of Gini Coefficient of egg producers and Retailers

\begin{tabular}{cccccccc}
\hline Range of income (N) & $\begin{array}{l}\text { Frequency } \\
\text { of sellers }\end{array}$ & $\begin{array}{l}\text { Percentage } \\
\text { of sellers }\end{array}$ & $\begin{array}{l}\text { Percentage } \\
\text { cum. freq. } \\
\text { of sellers }\end{array}$ & $\begin{array}{l}\text { Total } \\
\text { sale }(\mathbf{N})\end{array}$ & $\begin{array}{l}\text { Percentage of } \\
\text { total sale }(\mathbf{N})\end{array}$ & YX \\
\hline $10000-10001$ & 1 & 1.6 & 1 & 1.6 & 60000 & 0.95 & 0.00015 \\
$20000-20001$ & 3 & 5 & 4 & 6.6 & 324400 & 5.14 & 0.00257 \\
$30000-30001$ & 3 & 5 & 7 & 11.6 & 380000 & 6.02 & 0.00301 \\
$40000-40001$ & 4 & 6.7 & 11 & 18.3 & 425000 & 6.73 & 0.00451 \\
$50000-50001$ & 4 & 6.7 & 15 & 25 & 445000 & 6.33 & 0.00424 \\
$60000-60001$ & 5 & 8.3 & 20 & 33.3 & 355000 & 7.05 & 0.00585 \\
$70000-70001$ & 3 & 5 & 23 & 38.3 & 325000 & 5.62 & 0.00281 \\
$80000-80001$ & 3 & 5 & 30 & 63.3 & 500000 & 5.15 & 0,00258 \\
$90000-90001$ & 4 & 6.7 & 26 & 50 & 400000 & 7.91 & 0.00530 \\
$10000-10001$ & 6 & 10 & 36 & 60 & 850000 & 13.46 & 0.01346 \\
$>100000$ & 24 & 40 & 60 & 100 & 2251000 & 35.64 & 0.14256 \\
\hline Mean value of sale = N73333.93, Gini coefficient =1 (N)YX=1-(N)0.18704=0.81296 & & & &
\end{tabular}

\section{Profitability of egg marketing}

The result of gross margin analysis is presented in Table 3. The result showed that the cost of production of 227 crates per sale retail was N105.257 which was $98.4 \%$ of the total variable cost of the cost of transportation, storage, Packaging and labor accounted for $0.49,0.47,0.52$ and
0.12 percentages, respectively. The total variable cost per retail / seller was N106, $968 / 227$ crates of eggs while the total revenue per seller was N118, 997.50 for 227 crates of eggs. The gross margin per producer / seller was N12, 029.50. The result revealed that marketing of eggs in the study area is profitable.

Table 3: Gross margin analysis per seller of egg per month in the study area

\begin{tabular}{lll}
\hline Item & Amount $(\mathrm{N})$ & Percentage \\
\hline Cost of purchase of egg & $105,257.00$ & 98.40 \\
Transport cost & 503.33 & 0.49 \\
Storage cost & 525.25 & 0.47 \\
Packaging cost & 555.10 & 0.52 \\
Labor cost & 127.50 & 0.12 \\
Market tax & 125.00 & 100 \\
Total Variable cost per Seller & $106,968.00$ & \\
Total cost per Seller & $108,218.18$ & \\
Total Revenue per Seller & $118,997.50$ & \\
Gross Margin per Seller & $12,029.50$ & \\
Net Revenue per Seller & $10,779.50$ & \\
\hline
\end{tabular}

Source: Field Survey 2018 
Table 4: Marketing Margin for Eggs

\begin{tabular}{ll}
\hline Items & Amount $(\mathrm{N})$ \\
\hline Average farm gate price per crate of eggs & 800.00 \\
Average packaging cost per crate of eggs & 50.00 \\
Average transportation cost per crate of eggs & 40.50 \\
Market charges/tax per crate of eggs & 30.38 \\
Average labor cost per crate of eggs & 20.50 \\
Average retail price per crate of eggs & 1000.00 \\
Marketers profit per crate of eggs & 150.00 \\
Marketers margin per crate of eggs & 200.00 \\
\hline
\end{tabular}

Source: Field Survey 2018

\section{Marketing margin of respondents}

The result showed that the average farm gate price was N800 per crate of eggs. Average cost of packaging, transportation, tax, labor, retail price and marketers profit per crate of eggs were N 50.0.00, N40.50, $\mathrm{N} 30.38, \mathrm{~N} 20.50, \mathrm{~N} 1000.00$ and N150.00 in that order. Marketers margin per crate of eggs yielding a total margin of N200.00 which implied that there was a price different of N200.00 per crate of egg.

\section{Viability test}

The analysis shows that the business had a Benefit Cost Ratio (BCR) of 1.10. The $\mathrm{BCR}$ indicates that egg marketing is viable in the study area.

\section{Conclusion}

The study revealed that egg marketing and production is profitable in the Southern Zone of Plateau State. The business is highly recommended for youth in the zone as a means of gainful employment. The study also shows the inequality in the market structure by the high level of concentration in the market as seen in the Gini Coefficient and that majority of the respondents are in their active ages.

\section{Recommendations}

Egg production and marketing being a profitable economic activity, highly recommended as a means of gainful employment, poverty alleviation and arresting rural - urban human migration.
The production and marketing of eggs should be encouraged by individuals and institutions especially Colleges of Agriculture. Relevant government agencies and commercial banks should put programmed in place for granting loans to genuine poultry farmers and marketers to expand and improve their operations and by so doing ensure availability of eggs at prices affordable by all to upgrade the protein intake of an average Nigerians.

\section{References}

Afolabi, A. J. 2007. Evaluation of poultry eggs marketing in southern Nigeria International Journal of Poultry Science. 6(5):362-366.

Ashagidigbi, W. M., Suleman, S. A. and Adesanya, A. 2011. Technical and allocative efficiency of poultry eggs producers in Nigeria. Medwell Agricultural Journals 6 (4): 124130.

Ekunwe, P. A and Abufohai, 2009. Economic of poultry eggs marketing in Benin city, Edo State, Nigeria. International Journal of Poultry Science 8(2):166-169.

F.A.O. 2003. Egg food and agricultural organization (of the United Nation service bulleting No.150.

Fasakin, K. 1984. Integrated mixed farming feasibility report on the establishment of commercial 


\section{Profitability analysis of poultry egg production and marketing}

mixed farming enterprise for the production of table eggs, poultry meat and feeds, as well as some essential and cash crops unpublished.
Okuneye, P. A. 2002. Livestock SUBsector in Nigeria. Challenges and prospect, Bullion publication of CBN, vol. 26.No.3

Received: $10^{\text {th }}$ September, 2018 Accepted: $21^{\text {st }}$ December, 2018 